\title{
The Use of Full-Grained, Fragmented, and Reduced Marine Yeast Powder in Fodder Formulation to Improve the Growth of Eel Fish (Anguilla bicolor)
}

\author{
Ria Retno Dewi Sartika Manik ${ }^{1 *}$, Arning Wilujeng Ekawati ${ }^{2}$, Hardoko ${ }^{2}$ \\ ${ }^{1}$ Master Program, Faculty of Fisheries and Marine Sciences, University of Brawijaya, Malang, Indonesia \\ ${ }^{2}$ Faculty of Fiheries and Marine Scineces, University of Brawijaya, Malang, Indonesia
}

\begin{abstract}
Ikan Sidat or eel fish (Anguilla bicolor) is a popular fish commodity in domestic trade as well as for export commodity. The use of marine yeast as fodder suffers from some weaknesses since it contains nucleic acids and rigid thick cell walls that obstruct the absorbance of nutrition. Optimizing the use of marine yeast as fodder ingredients can be done by fragmenting and reducing the yeast. This research attempts at optimizing the use of marine yeast regarding its rate of growth, fodder efficiency and the survival rate of eel fish. This research employs the complete random design using 4 different treatments and 3 repetition. In the four treatments, the fodder contained protein (45\%) and iso energy $(3.600$ kkal. $\mathrm{kg}^{-1}$ fodder), which were applied to the treatment A 0\% (control), B 5\% (complete), C 5\% (fragmented) and D 5\% (reduced). The parameters used in this study were survival rate, specific growth rate, ratio of fodder conversion, ratio of protein efficiency, energy retention, protein retention and rate of metabolism. The data of this study showed the best result in the treatment $D, 5 \%$ (reduced), showing survival rate value of $95.56 \%$, specific growth at 1.12 , food conversion ratio of 2.27 , protein efficiency ratio of 0.98 , protein retention at $18.26 \%$, energy retention of 16.57 , and protein metabolism rate at $81.96 \%$.
\end{abstract}

Keywords: eel fish, growth, marine yeast.

\section{INTRODUCTION}

Eel fish (Anguilla bicolor) is a popular domestic and export fish commodity in Indonesia. The production of eel fish in the world has increased as much as $30.07 \%$ from the year 2000 at 210.228 tons to 273.449 tons in 2007 [1]. However, in 2008 to 2011, the aqua culture production of eel fish has been gradually decreased until at this present time [1].

Fodder for eel fish should contain a balance protein at about $40-50 \%$ which requires huge amount of ingredients that contain high protein such as fish powder and soya powder [2]. Marine yeast is a cellular organism with chemoorganotroph characteristics which has sexual reproduction using spores and asexually using buds or fission. Marine yeast contains high complex B vitamin (thiamin, riboflavin, nicotinate, and biotin) [3]. Marine yeast as the source of protein also has a number of benefits such as having high rate of growth, ability to grow in simple media, ability to grow at high cell solidity, high nutrients, high metabolism rate, non-toxic, easy to find and having no negative impact [4].

\footnotetext{
* Correspondence author:

Ria Retno Dewi Sartika Manik

Email : riaretnocantik@gmail.com

Address : Faculty of Fisheries and Marine Sciences, University of Brawijaya, Veteran St. Malang 65145
}

However, the use of marine yeast suffers from a problem in which the yeast contains nucleic acids and rigid thick cell wall components that obstruct the absorption of nutrition $[5,6,7]$. Optimizing the use of marine yeast as fodders can be done by reducing the nucleic acids and cell walls through fragmentation method and reduction method. Cells of the yeast were sliced through sonification treatment in which the yeast was sonificated for 20 minutes at the ultrasound of $20 \mathrm{kHz}$, producing protein release at $35 \%$ [8]. The best attempt to decrease the content of nucleic acids was the treatment at $\mathrm{pH}$ (2) and temperature of $90^{\circ} \mathrm{C}$ which produced nucleic acids up to $1.2 \%$ [9].

According to the explanations, it is necessary to conduct a research which deeply investigates the experiments using full-grained marine yeast without fragmentation and reduction compared to experiments using fragmented cell walls of marine yeast and marine yeast which nucleic acids are reduced. Besides, it is also important to explore the potency of marine yeast powder to use in fodder formulation and its influence in the growth of eel fish stadia elver by measuring the survival rate, specific rate of growth, fodder conversion ratio, efficiency ratio, energy retention, protein retention and metabolism rate. 


\section{MATERIALS AND METHODS}

The Making of Marine Yeast Powder

The first step in making the powder was culturing the marine yeast for 5 days. After five days, the marine yeast was filtered and drained for 3 days at room temperature. The making of fragmented marine yeast powder was conducted using sonicator at $20 \mathrm{kHz}$ frequency for 20 minutes [10] while the nucleic acids-reduced marine yeast powder was obtained by heating it up at the temperature of $90^{\circ} \mathrm{C}$ and adding the acidity at $\mathrm{pH}$ 2[9].

\section{Fodder Production}

The formulation of the fodder consisted of fish powder as the main ingredients, soya powder, polar powder and marine yeast powder which were added up with tapioca powder, cmc, $\mathrm{Cr}_{2} \mathrm{O}_{3}$, vitamins and minerals. Those ingredients were than mixed as the fodder that supplies good nutrition needed by the eel fish ( $A$. bicolor) with isoprotein of $45.01 \%$ and iso energy of 3.600 kkal. $\mathrm{kg}^{-1}$ [11]. The fodder formulation used in the experiment is presented in Table 1.

\section{Biological Test}

The different fodder products were then tested biologically, involving the eel fish ( $A$. bicolor) stadia elveras the subject of the experiment. The eel fish breeds ( $A$. bicolor) were obtained from Cilacap, Central Java. The fish had average length of around $15 \mathrm{~cm}$ and average weight of $7.08 \pm 0.22 \mathrm{~g}$ per fish which were kept in an $30 \times 30 \times 30 \mathrm{~cm}^{3}$ aquarium with freshwater as the media. In the outer part of the aquarium, black polybag plastics, aeration, and shelter were applied to keep the fish in a good condition [12]. The best distribution of the eel fish ( $A$. bicolor) was at $0.3 \mathrm{~kg} \cdot \mathrm{m}^{-2}$ [13]. The feeding was done at $3 \%$ of the biomass weight for twice a day with $40 \%$ fodder given at $08.00 \mathrm{am}$, and $60 \%$ at 19.00 pm [12].

Table 1. Fodder Formulation in the Experiment

\begin{tabular}{lcccc}
\hline \multirow{2}{*}{ Ingredients } & \multicolumn{4}{c}{ Treatment (\%) } \\
\cline { 2 - 5 } & $\mathbf{A}$ & $\mathbf{B}$ & $\mathbf{C}$ & $\mathbf{D}$ \\
\hline Fish powder & 54.67 & 54.67 & 54.67 & 54.67 \\
Soya powder & 27.85 & 26.46 & 26.46 & 26.46 \\
Polar powder & 8.07 & 8.07 & 8.07 & 8.07 \\
Marine yeast powder & 0.00 & 2.61 & 2.16 & 5.98 \\
Tapioca powder & 3.82 & 4.76 & 3.43 & 3.59 \\
Vitamins and Minerals & 1.50 & 1,50 & 1.50 & 1.00 \\
$\mathrm{Cr}_{2} \mathrm{O}_{3}$ & 0.50 & 0.50 & 0.10 & 0.10 \\
$\mathrm{CMC}$ & 3.59 & 1.43 & 3.61 & 0.14 \\
\hline Proximate Composition & & & & \\
\hline Ash (\%) & 15.33 & 15.22 & 15.68 & 17.65 \\
Protein (\%) & 46.13 & 45.14 & 45.53 & 45.36 \\
Fat (\%) & 17.88 & 17.88 & 15.69 & 18.00 \\
Rough fiber (\%) & 5.82 & 7.47 & 7.50 & 6.40 \\
BETN (\%) & 14.83 & 14.29 & 15.59 & 12.59 \\
DE (kkal.g ${ }^{-1}$ ) & 4.05 & 3.99 & 3.86 & 3.94 \\
\hline
\end{tabular}

\section{Statistical Analysis}

The data obtained from the experiment were then analyzed using quantitative measurement to see the survival rate, specific growth rate, feed conversion ratio, protein efficiency ratio, protein retention, energy retention and the metabolism rate of the fodder. The test was conducted using the variety test (ANOVA) which seek for any influences of the treatment which was then followed by Tukey test.

\section{RESULTS AND DICUSSION CML Serum Levels}

The result of the observation on each of the parameter in each treatment given during the experiment can be seen in Table 2.

Table 2. The Use of Marine yeast Powder in the Formulation of Fodders for Eel Fish (Anguilla bicolor)

\begin{tabular}{lcccc}
\hline Parameter & A (Control) & B (Full-grained) & C (Fragmented) & D(Reduced) \\
\hline Survival rate (\%) & $86.67 \pm 0.00^{\mathrm{a}}$ & $75.56 \pm 13.88^{\mathrm{a}}$ & $86.67 \pm 11.55^{\mathrm{a}}$ & $95.56 \pm 3.85^{\mathrm{a}}$ \\
SGR (\%/weight/day) & $0.74 \pm 0.03^{\mathrm{b}}$ & $0.51 \pm 0.04^{\mathrm{a}}$ & $0.70 \pm 0.06^{\mathrm{b}}$ & $1.12 \pm 0.08^{\mathrm{c}}$ \\
FCR & $3.46 \pm 0.16^{\mathrm{a}}$ & $5.07 \pm 0.36^{\mathrm{a}}$ & $3.54 \pm 0.32^{\mathrm{a}}$ & $2.27 \pm 0.17^{\mathrm{a}}$ \\
PER & $0.62 \pm 0.02^{\mathrm{b}}$ & $0.43 \pm 0.03^{\mathrm{a}}$ & $0.62 \pm 0.06^{\mathrm{b}}$ & $0.98 \pm 0.07^{\mathrm{c}}$ \\
Protein Retention & $7.56 \pm 1.14^{\mathrm{b}}$ & $3.00 \pm 1.26^{\mathrm{a}}$ & $6.69 \pm 1.74^{\mathrm{b}}$ & $18.26 \pm 1.32^{\mathrm{c}}$ \\
Energy Retention & $5.91 \pm 0.93^{\mathrm{b}}$ & $2.21 \pm 1.26^{\mathrm{a}}$ & $5.03 \pm 1.53^{\mathrm{b}}$ & $16.57 \pm 1.09^{\mathrm{c}}$ \\
Protein Metabolism Rate & $78.51 \pm 2.36^{\mathrm{a}}$ & $76.59 \pm 1.39^{\mathrm{a}}$ & $78.18 \pm 2.08^{\mathrm{a}}$ & $81.96 \pm 1.71^{\mathrm{b}}$
\end{tabular}

Notes : Similar notations show no differences, while different notations show different results among the treatments (level of trust at 95\%)

\section{Survival Rate}

Based on the data of survival rate, followed by the normality and homogeneity tests of the data using the SPSS program version 16.00 showed result that the data were homogeneous and were normally distributed. The result of the variety test showed one way variety (oneway ANOVA) which survival rate value of the eel fish 
(A. bicolor) was not far different among the treatments $(p>0.05)$.

The average survival rate value obtained from those treatments was 75.56-95.56\%. The highest survival rate value was found in the treatment $D$ at $95.56 \% \pm 3.85$, followed by the result of the treatment A $(86.67 \% \pm 0.00), C(86.67 \% \pm 11.55)$ and treatment $B(75.56 \% \pm 13.88)$, respectively. The result of this study shows relatively higher survival rate value compared to the other result [14] which was obtained by giving natural food which resulted to survival rate value of the eel fish ( $A$. bicolor)at $36.8 \%$. The mortality pattern of eel fish (A. bicolor)can be seen in Figure 1.

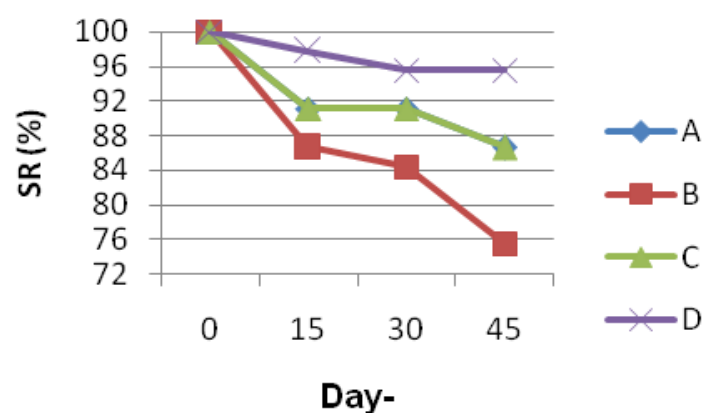

Figure 1. Mortality Pattern of Eel Fish (A. bicolor) Found during the Treatment

Description: SR = Survival Rate; The fodder contained protein $(45 \%)$ and iso energy (3.600 kkal. $\mathrm{kg}^{-1}$ fodder) applied to A $0 \%$ (control), B 5\% (complete), C 5\% (fragmented) and D 5\% (reduced).

The high value of survival rate found in this study might be caused by the reduced nucleic acids of the marine yeast at the dosage of $5 \%$ to substitute the use of soya powder in the fodder formulation which resulted to the best response toward fish' immunity. Marine yeast contains B complex vitamis such as thiamin, riboflavin, nicotinate and biotin. The B complex vitamin has been known to give some benefits such as producing the energy, maintaining the health of the nerve system, maintaining the digestive system and improving the cell production $[15,16]$.

\section{Specific Growth Rate}

Specific growth rate refers to the change of individual's weight within a certain time period. The graphic of eel fish' specific growth rate in this study is presented in Figure 2.

The best result was obtained when the marine yeast was reduced in the $D$ treatment with growth percentage at $1.12 \%$ weight $^{-1}$.day ${ }^{-1}$ followed by treatment $A\left(0.74 \%\right.$ weight $^{-1}$. day $\left.{ }^{-1}\right)$,
C $\left(0.70 \%\right.$ weight $^{-1} \cdot$ day $\left.^{-1}\right)$, and B $(0.51 \%$ weight ${ }^{1} \cdot$ day $\left.^{-1}\right)$. The result of the specific growth rate (SGR) found in this study is relatively higher than the result of research [12] which formulated the fodder using the silage of fermented pace leaves and $L$. plantarumat $0.37-0.73 \%$ weight $^{-1}$. day ${ }^{-1}$. However, the result of this study is close to the result of research [17] which treated the fish with natural fodder with specific growth rate at $0.66-$ $1.096 \%$ weight $^{-1}$. day ${ }^{-1}$.

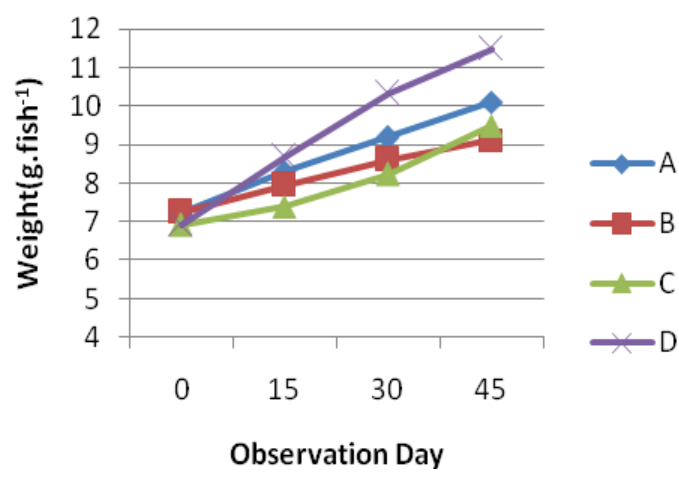

Figure 2. The Eel Fish's Growth

Description: The fodder contained protein (45\%) and iso energy (3.600 kkal. $\mathrm{kg}^{-1}$ fodder) applied to A $0 \%$ (control), B 5\% (complete), C $5 \%$ (fragmented) and D 5\% (reduced).

The problem in the use of marine yeast as fodder relies on the high amount of nucleic acids which limits the absorption of nutrition [5]. Therefore, in this study, the marine yeast undergone three different treatments to decrease the amount of nucleic acid by keeping it full-grained, fragmented and reduced as presented in Table 3. The result of this study showed that the lesser the amount of nucleic acid in marine yeast, the higher the specific growth rate of the eel fish (A. bicolor). The result of the nucleic acid found in this study is relatively low than the previous results of research which reduced yeast conducted $\mathrm{pH} 2$ and temperature $90^{\circ} \mathrm{C}$ produced $1.2 \%$ nucleic acids [9].

Table 3. Nucleic Acids in Marine Yeast

\begin{tabular}{cc}
\hline Marine Yeast & Nucleic Acid Content (\%) \\
\hline Full-grained & $11,72 \pm 0.22$ \\
Fragmented & $9,29 \pm 0.16$ \\
Reduced & $1,40 \pm 0.04$ \\
\hline
\end{tabular}

\section{Fodder Conversion Ratio}

The average value of fodder conversion ratio of eel fish ( $A$. bicolor) during this research varied from $2.27 \%$ - 5.07. These values are smaller compared to the results of previous research which found values of fodder conversion ratio at 
6.73 with natural fodder and 9.91 with $25 \%$ formulated fodder and $75 \%$ natural fodder[18].

The value of fodder conversion ratio is affected by several factors including the quality and quantity of the fodder, the species of fish, water amount and water quality. The increase on the value of fodder conversion ratio is influenced by the high amount of nutrients which are not optimally absorbed by the body or wasted through the feces [19].

\section{Protein Efficiency Ratio}

The average of protein efficiency ratio of the eel fish ( $A$. bicolor) recorded in this study varied between $0.43-0.98$. The value of protein efficiency ratio is affected by the protein quality in the fodder in which the higher the value of protein efficiency ratio, the better the quality of the protein in the fodder which improves the growth rate of the eel fish ( $A$. bicolor) [20]. Protein quality of fodder ingredients is determined by the amount of amino acids in the ingredients especially the essential amino acids (arginine, histidine, isoleusin, leusin, lysine, methionine, phenylalanine, threonine, tryptophan and valine). Amino acids in the fullgrained marine yeast, fragmented marine yeast, and reduced marine yeast showed positive correlation in which the higher the amount of essential amino acids, the higher the protein efficiency ratio. The amount of essential amino acids found in this study can be seen in Figure 3 .

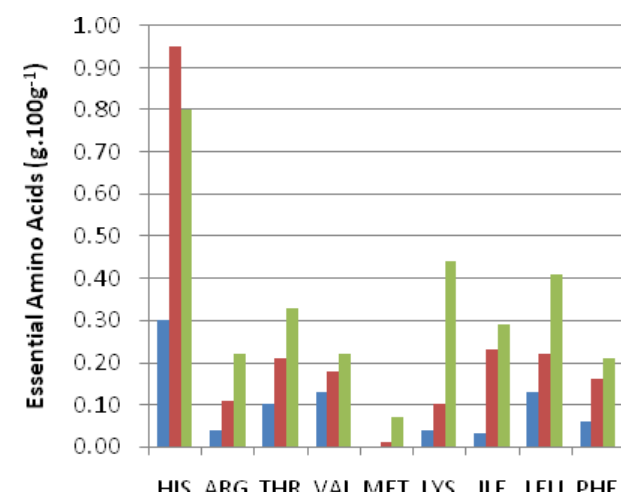

Figure 3. The Amount of Essential Amino Acids in The Full-Grained, Fragmented, and Reduced Marine Yeast Powder

Description: HIS= Histidine, $A R G=$ Arginine, $\mathrm{THR}=$ Threonine, $\mathrm{VAL}=$ Valine, $\mathrm{MET}=$ Methionine, LYS= Lysine, ILE= Isoleusin, LEU= Leusin, $\mathrm{PHE}=$ Phenylalanine

\section{Protein Retention}

Protein retention is the reflection of the amount of absorbed protein to build and heal the broken cells and which is used to maintain the metabolism system [20]. Based on the result of the Tukey test, it can be seen that the treatment D showed obviously best result at $18.26 \%$ compared to the other treatments, followed by treatment A (7.56\%), C (6.69\%) and B (3.00\%).

The average value of protein retention in this study varied between $3.00-18.29 \%$. The value of the protein retention found in this study is a little bit higher than the result of research [11] at 1.31 - $13.22 \%$ using formulated fodder with different protein and energy ratios. The excretion process and the catabolism of amino acids require high amount of energy, making the allocation of the energy to retain the protein in the body decreased. Protein retention is influenced by various factors such as the amount of the protein in the fodder, the balance of amino acids amount and fodder energy ratio [21].

\section{Energy Retention}

The result of the Tukey test applied to the treatment $D$ showed obvious difference from the result of the measurement employed to the $A, B$, and $C$ treatments. Based on the result of this study, the use of reduced marine yeast in treatment $D$ gave the most significant influence to the energy retention as much as $16.57 \%$ followed by the treatment A (5.91\%), C (5.03\%) and $B(2.22 \%)$. The average value of the energy retention found in the eel fish ( $A$. bicolor) found in this study varied between $2.22016 .57 \%$. The result of this study shows higher result than the other research in which $100 \%$ of paste fodder resulted to energy digestion rate at $10.77 \%$ [22].

The possible explanation of this phenomena is that this phenomena happens due to the energy produced is being used by the body to run the metabolism process, reproduction process, biosynthesis and wasted in the form of heat. The saved energy is then used for the cell components synthesis as the fuel in the production of cell energy [23]. Growth occurs when there is extra energy that remains after being used in the basic live supports [24]. In the optimal environment condition, the growth is mainly influenced by the fodder given.

\section{Protein Metabolism}

The result of the Tukey test showed that the treatment in which marine yeast was reduced as the substitution showed obviously different results from the results of other treatments. Based on the graphic above, the best protein 
metabolism during the experiment was found in the treatment $D$ at $81.90 \%$ followed by the treatment A (78.51\%), C (78.18\%) and B (76.59\%).

The average protein metabolism value of eel fish ( $A$. bicolor) during this study was found between $76.59-81.90 \%$. This value is lesser than the result of a study in which the formulated fodder was added up with marine yeast to substitute the use of soya powder for humpback fish (Cromileptes altivelis) which showed value of protein metabolism of $56.56-84.91 \%$ [25].

The process of protein digestion from the fodder starts inside the fish's stomach. Protein from the fodder will undergo the denaturation process by the HCL which is then hydrolyzed by pepsin enzyme which turns the protein into peptide. Furthermore, inside the intestines, the peptide will also undergo the hydrolysis process with the carboxypeptidase, chymotrypsin trypsin and elastase as the catalizador. After that, this oligopeptide will be hydrolyzed by the peptidase enzyme to change formation as tripeptid, dipeptide and amino acids [26].

\section{CONCLUSION}

The full-grained, fragmented and reduced marine yeast can be used in the formulation of fodder to substitute the protein from soya powder which gives positive effect on the growth of eel fish ( $A$. bicolor). The reduced marine yeast powder contains nucleic acid of around 1.40 and its high amount of essential amino acids offers best result on the growth of the fish compared to other treatments. Marine yeast powder contains high protein and high amino acids which can be used in the fodder to substitute the use of soya powder. Future researchers are encouraged to conduct research to investigate the use of marine yeast powder at higher dosage in order to find the maximum point of the reduced marine yeast powder.

\section{REFERENCES}

[1] Food and Agriculture Organization of the United Nationss (FAO). 2014. GLOBEFISH, product, trade and marketing service fisheries and aquaculture policy and economics division. Washingtong DC, USA.

[2] Yaniharto, E., O. Rovara, I.E. Setiawan. 2013. Subtitusi tepung ikan impor dengan tepung ikan lokal dan tepung bungkil kedelai dalam pakan untuk pemeliharaan ikan sidat (Anguilla bicolor) di kolam (hapa). E-paper in Conference of Aquaculture Indonesia. 373-378.

[3] Feldmann, H. 2012. Yeast molecular and cell biology. Wiley-Blackwell. Germany.

[4] Ramesh, C.K., A. Singh, K.K. Tripathi, R.K. Saxena, K.E.L. Eriksson. 1997. Microorganism as an alternative source of protein. Nutr. Rev. 55(3). 65-75.

[5] Anupama, P. Ravindra. 2000. Value-added food: single cell protein. Biotech. Adv. 18. 459-479.

[6] Gao, L., Z.M. Chi, J. Sheng, X. Ni. 2007. Single-cell production from jerusalem artichoke extract by a recently isolated marine yeast Cryptococcus aureus g7a and its nutritive analysis. Appl. Microbiol. Bioethanol. 77. 825-832.

[7] Chi, Z., G.L. Liu, Y. Lu, H. Jiang, Z.M. Chi, L. Wang. 2015. Bio-product produced by marine yeast and their potential applications. Biores. Tech. 202. 244-252.

[8] Bałdyga, J., M. Jasińska, M. Dzięgielewska, M. Żochowska. 2012. Disruption of yeast cells with ultrasound. European Conference on Mixing Warszawa. Poland. 25-30.

[9] Zee, J.A., R.E. Simard. 1975. Simple process for the reduction in the nucleic acid content in yeast. Am. Soc. Microbiol. 29(1). 59-62.

[10] Liu, D., X.A. Zeng, D.W. Sun, Z. Han. 2013. Distruption and proteins release by ultrasonications of yeast cells. Innov. Food Sci. Emerg. 18. 496-500.

[11] Nawir, F, N.B.P. Utomo, T. Budiardi. 2015. Pertumbuhan ikan sidat yang diberi kadar protein dan rasio energi protein pakan berbeda. Jurnal Akuakultur Indonesia. 14(2). 128-134.

[12] Cholifah, D., M. Febriani, A.W. Ekawati, Y. Risjani. 2012. Pengaruh penggunaan tepung silase daun mengkudu (Morinda citrifolia) dalam formula pakan terhadap pertumbuhan ikan sidat (Anguilla bicolor) stadia elver. Jurnal Kelautan. 5(2). 93-107.

[13] Degani, G., A. Horowitz, D. Levanon. 1985. Effect of protein level in purified diet and of density, ammonia and $\mathrm{O}_{2}$ level on growth of juvenile europeaneels (Anguilla anguilla L.). Aquaculture. 46. 193-200.

[14] Sasongko, A., Purwanto, S. Mu'minah, Arie. 2007. Sidat: panduan agribisnis penangkapan, pendederan dan pembesaran. Penebar Swadaya. Jakarta.

[15] Becker, E.W. 1994. Microalgae: biotechnology and microbiology. Cambridge University Press. Cambridge. 
[16] Schrimshaw, N.S., E.B Murray. 1995. Nutritional value and safety of single cell protein. In: Rhem, H.J., R. Gerald (Eds). Biotechnology, $2^{\text {nd }}$ Completely Revised Ed. Wiley-VCH. Weinheim. 9. 221-237.

[17] Purwanto, J. 2007. Pemeliharaan benih ikan Sidat (Anguilla bicolor) dengan padat tebar yang berbeda. Buletin Teknik Literatur Akuakultur. 6(2). 85-89.

[18] Arief, M., D. Pertiwi, Y. Cahyoko. 2011. Pengaruh pemberian pakan buatan, pakan alami dan kombinasinya terhadap pertumbuhan, rasio konversi pakan dan tingkat kelulushidupan ikan sidat (Anguilla bicolor). Jurnal IImiah Perikanan dan Kelautan. 3(1). 61-65.

[19] National Research Council. 1993. Nutrient requirement of fish. National Academic of Science. Washington, D.C.

[20] Buwono, I.D. 2000. Kebutuhan asam amino esensial dalam ransum ikan. Kanisius. Yogyakarta.

[21] Ali, A., SM. Al-Ogaily, N.A. Al-Asgah, J.S. Goddard, S.I. Ahmed. 2008. Effect of different protein to energy $(P / E)$ rations on growth performance and body compositions of Oreochromis niloticus fingerlings. J. Appl. Ichthyol. 24. 31-37.

[22] Yudiharto, S., M. Arief, Agustono. 2012. Pengaruh penambahan atraktan yang berbeda dalam pakan pasta terhadap retensi protein, lemak dan energi benih ikan sidat (Anguilla bicolor) stadia elver. Jurnal Ilmiah Perikanan dan Kelautan. 4(2). 135140.

[23] Subekti, S., M. Prawesti, M. Arief. 2011. Pengaruh kombinasi pakan buatan dan pakan alami cacing sutera (Tubifex tubifex) dengan persentase yang berbeda terhadap retensi protein, lemak dan energi pada ikan sidat (Anguilla bicolor). Jurnal Kelautan. 4(1). 1-6.

[24] Kamil, M.T. 2000. Pengaruh kadar asam lemak n-6 yang berbeda pada kadar asam lemak yang berbeda $n-3$ tetap dalam pakan terhadap pertumbuhan ikan sidat (Anguilla bicolor-bicolor). Master Thesis. Graduate Program of Marine Science, Bogor Agricultural Univeristy. Bogor.

[25] Febriani, M. 2001. Studi khamir laut sebagai sumber nutrisi potensial untuk pakan ikan kerapu tikus (Cromileptes altivelis). Master Thesis. Graduate Program of Marine Science. University of Brawijaya. Malang.
[26] Fuzaya, Y. 2004. Fisiologi ikan. Rineka Cipta. Jakarta. 